\title{
De bewogen beginjaren van de Nederlandsche Bioscoop Bond, 1918-1925
}

Op i6 juli I992 kwam een eind aan het bestaan van een van de machtigste brancheorganisaties die ons land ooit heeft gekend: de Nederlandse Bioscoopbond (NBв). De opheffing was afgedwongen door de Europese Gemeenschap, die eind jaren tachtig vaststelde dat de NBB zo'n sterke greep had op zowel de filmdistributie als de filmvertoning in Nederland, dat dit onverenigbaar was met de Europese mededingingswetgeving. De Nвв diende te decentraliseren tot een federatieve structuur. Dat proces eindigde in 1992 met de vervanging van de NBB door een nieuwe brancheorganisatie: de Nederlandse Federatie voor de Cinematografie. ${ }^{\mathrm{I}}$

De geschiedenis van de NBв is meermaals beschreven, maar de door filmhistorici meestal geciteerde weergave is die van Karel Dibbets in de bundel Geschiedenis van de Nederlandse film en bioscoop tot $1940 .{ }^{2}$ Wie nagaat hoe in latere publicaties op basis van deze bron de NBBgeschiedenis kort wordt samengevat, moet concluderen dat Dibbets er vooral in is geslaagd duidelijk te maken dàt de Nвв het Nederlandse filmbedrijf lange tijd volledig controleerde. Wat echter niemand meer memoreert, is dat de in I92I opgerichte NBB tijdens de eerste jaren van haar bestaan helemaal nog niet zo'n sterke positie had en het er zelfs enige tijd naar uitzag dat de centralistische NBB-visie op de organisatie en belangenbehartiging van het Nederlandse filmbedrijf het zou afleggen tegen een van de alternatieve visies die indertijd circuleerden. Karel Dibbets zelf merkte in zijn bijdrage aan genoemde bundel wel op dat de definitieve consolidatie van de machtspositie van de NBв pas zijn beslag kreeg in I927, maar hij wierp daarbij slechts een beperkt licht op de omstandigheden die deze consolidatie tot een moeizaam verlopend proces maakten en zweeg over de alternatieve organisatie- en belangenbehartigingsmodellen die in omloop waren. Nieuw onderzoek op basis van primaire bronnen maakt het mogelijk hier de vroege geschiedenis van de NBв nader te belichten en daarmee een precisering te bieden van het beeld dat Karel Dibbets in I986 schetste.

\section{Booming business, Amerikaanse overmacht en lastige overheden}

De vorming van de NBB was de uitkomst van een combinatie van voornamelijk contextuele ontwikkelingen waarmee het Nederlandse filmbedrijf tijdens en kort na de Eerste Wereldoorlog te maken kreeg. Om te beginnen was er de opvallende toename van de vraag naar bioscoopvertier, in het bijzonder vanaf de tweede helft van I9I6. ${ }^{3}$ Het aantal bioscoopbedrijven groeide hierdoor niet heel sterk, maar wel de schaal van een aantal van die ondernemingen en het aantal film import- en verhuurbedrijven. Anno I9I4 werd de filmhandel normaliter gecombineerd met de 
exploitatie van een of meer bioscopen, waarbij slechts voor een beperkt aantal ondernemers het importeren en verhuren van films de hoofdactiviteit was. Voor zover bekend waren er in I9I4 ongeveer tien bedrijven van dat laatste type. Eind I920 waren het er minimaal twintig. ${ }^{4}$ Het aantal filmimport- en verhuurbedrijven in Nederland werd zelfs zo groot dat dit tot problemen leidde, in het bijzonder toen na I9I8 ten volle merkbaar werd hoe tijdens de oorlogsjaren op mondiaal niveau het filmbedrijf er totaal anders uit was gaan zien. In de productiesector hadden de Fransen definitief hun leidende positie verloren aan de Amerikanen en - binnen Europa aan de Duitsers. Al tijdens de oorlog moesten Nederlandse filmimporteurs zien in te spelen op deze internationale ontwikkelingen, een opgave waar de een beter in slaagde dan de ander. Nog veel sterker werden deze veranderingen merkbaar na I5 maart I9I9, toen de tijdens de oorlogsjaren door de Nederlandsche Overzee Trustmaatschappij gereguleerde in- en uitvoer van films weer werd vrijgegeven. ${ }^{5}$ Filmimporteurs konden nu onbelemmerd zaken doen met de Amerikaanse filmstudio's, waarvan de producten ook bij het Nederlandse publiek en dus bij de Nederlandse bioscoopexploitanten in de smaak vielen. ${ }^{6} \mathrm{Al}$ snel werd echter duidelijk dat het Nederlandse filmimportbedrijf zo versnipperd en kleinschalig was, dat het voor de Amerikanen een koud kunstje was de verschillende importeurs voortdurend tegen elkaar uit te spelen en zo te dwingen tot het betalen van hoge huurprijzen. Bovendien bleken zelfs de grootste Nederlandse filmimport- en verhuurbedrijven nog steeds te klein en te 'arm' om de nieuwste en beste Amerikaanse films te kunnen krijgen. Dat was vervelend voor de importeurs, maar ook voor de bioscoopexploitanten, want zij kregen de hoge huurprijzen natuurlijk gewoon doorberekend en bleven bovendien verstoken van de films die ze het liefst zouden willen draaien.7 Zolang het publiek desondanks massaal naar de bioscopen bleef komen, viel hiermee nog te leven. Problematisch werd het, toen men in de loop van I920 begon te merken dat de hausse op zijn einde liep. Vanaf dat moment - en we zullen nog zien hoe dat precies in zijn werk ging - begon de wens een einde te maken aan deze ongunstige importpositie te functioneren als drijvende kracht achter de professionalisering en integratie van de bedrijfstak.

Er was echter nog een andere drijvende kracht in het spel: een kracht die zich al had aangediend vóór het uitbreken van de oorlog, die beduidend sterker werd tijdens de oorlog en zeker niet zwakker toen na I920 het filmbedrijf te kampen kreeg met een neergaande conjunctuur. Die kracht was de negatief gerichte bemoeienis van de overheid met het filmbedrijf en in het bijzonder met de bioscoopexploitatie. Deze inmenging was begonnen zo rond I9I2, toen diverse gemeenten een lokale filmkeuring invoerden. Dit gebeurde veelal op instigatie van confessionele activisten en lokale politici, omdat zij de bioscoop beschouwden als een leerschool in zedeloosheid en crimineel gedrag, waar vooral het jeugdige publiek tegen beschermd moest worden. Naarmate het de bioscopen tijdens de oorlogsjaren meer voor de wind ging, spanden de 'bioscoophaters' zich des te harder in en in november I9I8 werd met het instellen van de regeringscommissie-Ledeboer de strijd tegen het 'bioscoopgevaar' zelfs een kwestie waarmee de landelijke politiek zich bezighield. De commissie kreeg van de regering opdracht te onderzoeken welke overheidsmaatregelen nodig waren om het bioscoopgevaar te beteugelen. Daarmee kwam een landelijke bioscoopwet in voorbereiding. Bovendien bracht de hausse in het bioscoopbedrijf menig gemeentebestuur tijdens de oorlogsjaren op het idee de vermakelijkheidsbelasting fors te verhogen, soms zelfs een aantal keren na elkaar. ${ }^{8}$

Bioscoopexploitanten zagen het allemaal met lede ogen aan en herhaaldelijk klonken uit 
hun midden oproepen om de krachten te bundelen en in verzet te komen tegen wat zij zagen als unfaire behandeling en systematische benadeling van hun bedrijfstak door de overheid. De eerste aanzetten tot zo'n krachtenbundeling kregen vorm op lokaal niveau in de drie grootste steden van het land. In Rotterdam gebeurde dat al in september I9I3, in antwoord op de invoering van een gemeentelijke filmkeuring. De bioscoopondernemers werkten hier van meet af aan samen met de exploitanten van variététheaters en later - toen verhogingen van de vermakelijkheidsbelasting de hele amusementssector troffen - ook met uitbaters van nog andere uitgaansgelegenheden. ${ }^{9}$ Enkele weken na het Rotterdamse initiatief riepen enkele Haagse bioscoopexploitanten hun Vereeniging voor de Belangen van Bioscoop-exploitanten 'Kino' in het leven, om gezamenlijk front te kunnen maken tegen de 'vijanden van de bioscoop'..$^{\text {Io }}$ In Amsterdam kwam het midden I9I6 tot de vorming van een vereniging van bioscoopexploitanten, waarbij overigens de oprichting van een lokale vakbond van bioscooppersoneel de directe aanleiding was. Pogingen om de bioscoopondernemers op landelijk niveau te organiseren werden eveneens ondernomen, maar bleven aanvankelijk zonder succes. ${ }^{\text {II }}$ Wel verschenen vanaf I9I2 de eerste vakbladen voor het bioscoopbedrijf en werd er vanaf november I9I6 op initiatief van een aantal filmverhuurbedrijven in Amsterdam een wekelijkse filmbeurs georganiseerd, waar elke maandag bioscoopexploitanten uit het hele land naartoe kwamen om bij de zich op de beurs presenterende verhuurders een nieuw weekprogramma te huren. ${ }^{12}$ Vanzelfsprekend ontmoetten de exploitanten op die beurs ook elkaar en namen de gelegenheid te baat om week in week uit alles wat hun branche betrof te bespreken. De beurs werd zo een informeel overlegplatform, van waaruit de stap naar vorming van een officiële, landelijke brancheorganisatie relatief makkelijk te nemen viel. Begin I9I8 kwam dat er ook van.

\section{De Bond van Exploitanten van Nederlandsche Bioscooptheaters}

In december I9I7 en januari I9I8 waren in de filmvakbladen De Bioscoop Courant en De Kinematograaf krachtige pleidooien te lezen voor solidariteit, samenwerking en gezamenlijk verzet van bioscoopondernemers tegen de vele beperkingen die zij door gemeentelijke overheden kregen opgelegd. Het was niet de eerste keer dat de vakbladen zulke oproepen publiceerden, maar anders dan voorheen werd er nu gehoor aan gegeven. Wat meehielp, was een nieuw geval van kneveling door lokale autoriteiten, dat zich voordeed in Maastricht. Daar had de gemeenteraad besloten de vermakelijkheidsbelasting voor bioscopen op te schroeven naar 25 procent van de bruto omzet. In één moeite door stelde de raad een bioscoopverbod in voor de jeugd tot achttien jaar. Willem van Lier, exploitant van de plaatselijke Cinema Pathé, zond een 'hulpkreet uit het Zuiden' naar de redactie van De Bioscoop Courant. Hij riep zijn collega's op zich aaneen te sluiten in wat hij een vakbeweging noemde. ${ }^{13}$ Daarop nam de Utrechtse bioscoopexploitant David Hamburger jr. ${ }^{14}$ tijdens de in Amsterdam gehouden filmbeurs van II februari I9I8 het initiatief om een vergadering van bioscoopdirecteuren en filmverhuurders te beleggen, die zich na de beurs in Café Schiller aan het Rembrandtplein zou buigen over een gezamenlijk actieplan. De circa veertig aanwezigen vormden een actiecomité van vijf leden, waarvan als voorzitter de Haagse bioscoopdirecteur Loet C. Barnstijn optrad. Een week later viel het besluit tot oprichting van de Nederlandsche Vereeniging van Bioscoop Exploitanten (ook aangeduid als de Bond van Exploitanten van Nederlandsche Bioscooptheaters), die tot midden 
maart geleid werd door een voorlopig bestuur. ${ }^{15}$ Het definitief benoemde bestuur bestond uit zeven leden, waarvan de bioscoopexploitant Willy Mullens uit Den Haag de voorzitter was. De vereniging telde bij aanvang volgens het vakblad De Filmwereld ongeveer honderd leden. ${ }^{\mathrm{I}}$

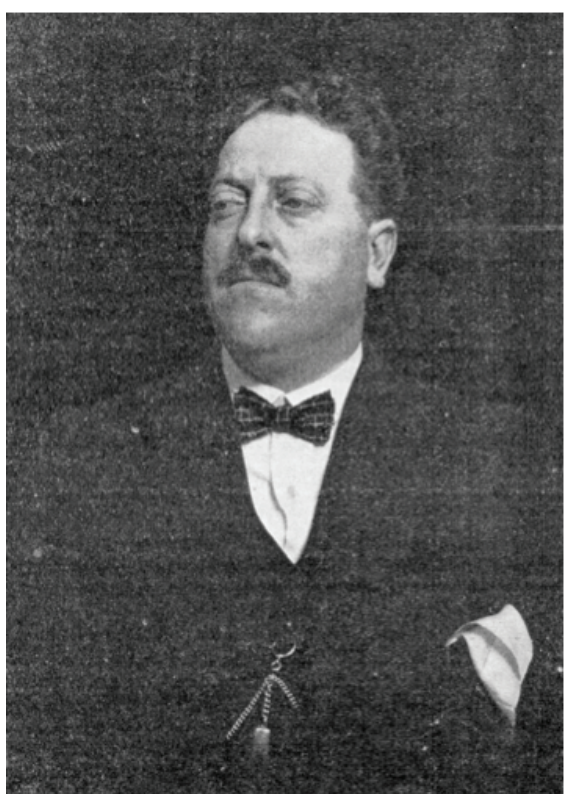

David Hamburger Jr Bron: NWC/Nieuw Weekblad voor de Cinematografie, 23 juli 1926 (EYE bibliotheek)

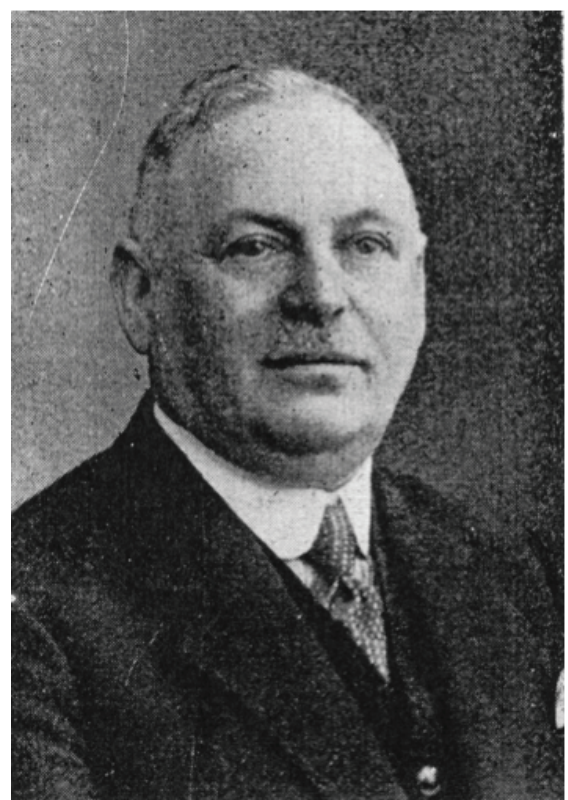

Elias de Hoop

Bron: NWC, 31 juli 1931

Opvallend aan de samenstelling van het bestuur was dat enkele bestuursleden (Mullens en Nöggerath) bioscopen bezaten in verschillende steden en eveneens enkele bestuursleden (Nöggerath en Barnstijn) behalve bioscoopexploitant óók belangrijke filmimporteurs en -verhuurders waren. ${ }^{17}$ Het lidmaatschap van de bond was alleen toegankelijk voor bioscoopexploitanten, niet voor filmverhuurders en dus zaten Nöggerath en Barnstijn officieel niet 'met hun verhuurderspet op' in het bestuur. ${ }^{18}$ Maar dat neemt niet weg dat met hun aanwezigheid het bondsbestuur de facto óók een open oog had voor de belangen van het verhuurbedrijf. Het probleem was dat die belangen lang niet altijd overeenkwamen met de belangen van de bioscoopexploitanten, in het bijzonder waar het ging om exploitanten van slechts één of hooguit twee bioscopen in een en dezelfde stad. Zulke bioscoopondernemers, en in I9I8 vormden die de overgrote meerderheid binnen de branche, opereerden vrijwel volledig binnen een beperkte, lokale context. Dáár bevonden zich het publiek, de concurrenten en de overheidsinstanties van bouwpolitie en belastinginner tot eventuele keuringscommissie - waar ze van dag tot dag mee te maken hadden. Voor zover hun ondernemerspraktijk zich uitstrekte buiten de lokale context, betrof dat eigenlijk alleen het contact met de filmverhuurders. En die verhuurders opereerden juist niet binnen een lokale, maar op z'n minst binnen een regionale en - in geval van de groten, zoals Nöggerath en Barnstijn - nationale context. Als importeurs werkten ze zelfs in een internationale context. Vanuit die omstandigheid hadden filmverhuurders een veel directer en veelzijdiger belang bij integratie, schaalvergroting en regulering op nationaal niveau van de praktijken en processen die met elkaar het bioscoopbedrijf concreet gestalte 
gaven. Immers, voor hen leverde dat met zekerheid een wezenlijke vereenvoudiging van hun eigen bedrijfsproces en dus een kostenbesparing op. Die kostenbesparing kon weliswaar in theorie ook leiden tot lagere huurprijzen voor de bioscoopexploitanten, maar of dat echt zo zou uitpakken was maar de vraag. Voor een puur lokaal opererende bioscoopondernemer was eigenlijk maar één ding echt belangrijk als het ging om de werkzaamheid van de landelijke Exploitantenbond, en dat was - zodra nodig - steun te krijgen voor zijn lokale verzet tegen negatief gerichte overheidsbemoeienis met zijn bedrijf.

Tijdens de eerste maanden van het bestaan van de Exploitantenbond was al goed merkbaar dat enerzijds de bestuursleden - in meerderheid ondernemers met niet puur lokaal opererende bedrijven - en anderzijds de 'gewone', kleine bioscoopexploitanten, die het merendeel van het ledental uitmaakten, in verschillende universa leefden. Het bestuur spande zich in om allerlei zaken te regelen die het lokale niveau overstegen. Kwamen de gewone leden in vergadering bijeen, dan maakten die vooral ruzie met elkaar, of uitten verdachtmakingen aan het adres van een bestuurslid. ${ }^{19}$ Zolang het bestuur ondanks dat geruzie nog min of meer haar gang kon gaan, functioneerde de bond toch als een kracht ten dienste van integratie en schaalvergroting binnen de branche en bevorderde daarmee dus in feite vooral de belangen van de grotere, op een bovenlokaal niveau werkende bioscoopbedrijven èn van de filmverhuurders, die niet eens lid waren van de bond. De kink kwam in de kabel toen begin I9I9 het merendeel van de filmverhuurders vond dat ze hun eigen belangen nog veel steviger moesten gaan bevorderen en daarvoor ook een eigen organisatie nodig hadden, los van de Exploitantenbond.

Dat de verhuurders tot deze stap besloten, had twee aanleidingen. In de eerste plaats kregen ze steeds vaker te maken met bioscoopexploitanten die niet of te laat hun filmhuur betaalden. Als dwangmiddel kon een filmverhuurder in zulke gevallen de wanbetaler treffen met een leveringsboycot, maar dat werkte alleen als de wanbetaler ook van concurrerende verhuurders geen films meer kreeg. Om dat te regelen, was een eigen organisatie van verhuurkantoren nodig. ${ }^{20}$ In de tweede plaats wilde een aantal filmverhuurders zich weren tegen de provocerende en aanmatigende manier waarop één van hen, Loet Barnstijn, zich als directeur van het filmverhuurbedrijf HAP presenteerde in het vakblad de Bioscoop-Courant. Om het populair te zeggen: Barnstijn deed alsof hij de Bioscoop-Courant en in feite de hele Nederlandse filmwereld 'in zijn zak had' en dat beviel zijn concurrenten niet. ${ }^{21}$

Beide aanleidingen samen brachten de verhuurders ertoe in januari I9I9 een aparte Vereeniging van Filmverhuurkantoren op te richten, waar Barnstijn aanvankelijk buiten stond. De exploitanten vreesden nu voor blokvorming in de verhuurbranche - Barnstijn tegen de samenspannende rest - waarbij die rest wel eens aanstoot zou kunnen gaan nemen aan het feit dat de Exploitantenbond Barnstijn als vice-voorzitter had. Zo kon het er immers op lijken dat de Exploitantenbond in het conflict tussen de verhuurders aan Barnstijns kant stond en zelfs volledig naar zijn pijpen danste. Barnstijn zag het probleem en trad af als vice-voorzitter. Nöggerath, de andere grote filmverhuurder in het bestuur, deed hetzelfde. Wel bleven beiden als bioscoopexploitanten - gewoon lid van de Exploitantenbond.

Het terugtreden van beide filmverhuurders uit het bestuur kon echter niet voorkomen dat allerlei grote en kleine kwesties de bond in I9I9 en I920 parten bleven spelen. Zo kreeg zij in mei I9I9 concurrentie van een nieuw opgerichte Bond van Directeuren van Publieke Vermakelijkheden, die zich mede opwierp als belangenbehartiger van het bioscoopbedrijf. 
Aanvankelijk was de onderlinge verhouding nog goed, maar tegen het eind van I9I9 lagen beide bonden al met elkaar overhoop..$^{22}$ Midden 1920 was er een conflict tussen de Exploitantenbond - inmiddels omgedoopt tot Nederlandsche Bond van Bioscooptheater-Directeuren ${ }^{23}$ - en de Verhuurdersvereeniging over de organisatie van de wekelijkse filmbeurs. Toen dat conflict de wereld uit was, kwam er trammelant tussen het bondsbestuur en een flink aantal Rotterdamse bioscoopexploitanten, die geen contributie wensten te betalen aan de landelijke bond, omdat ze al betaalden aan hun plaatselijke vereniging en dat wel genoeg vonden. De boel kwam op scherp te staan toen de Rotterdamse exploitanten in december 1920 wegbleven van de door de Bond van Bioscooptheater-Directeuren georganiseerde filmbeurs en een eigen wekelijkse filmbeurs begonnen. ${ }^{24}$ De bioscopen in de Maasstad vormden een te interessant marktsegment voor de filmverhuurders om zo maar te laten schieten en dus kwamen ze braaf naar de alternatieve beurs van de Rotterdammers, wat de positie van de Directeurenbond als organisator van de reguliere filmbeurs natuurlijk verder ondergroef. Dat deed ook de stokkende ledenaanwas. Medio I920 telde Nederland 230 bioscopen..$^{25}$ Het aantal bioscoopdirecties dat lid was van van de Directeurenbond bleef steken op circa I30. ${ }^{26}$ Kortom, als drijvende kracht achter de organisatie en integratie van de vaderlandse bioscoopbranche had de Nederlandsche Bond van Bioscooptheater-Directeuren eind I920 veel van zijn aanvankelijke momentum verloren. Degenen die het grootste belang hadden bij dat proces (en zoals gezegd waren dat de landelijk opererende filmondernemers) zagen om naar andere instrumenten. Een van hen was de voormalig vice-voorzitter Loet Barnstijn. Het is van belang hier kort stil te staan bij wat hij inmiddels op zakelijk gebied aan het doen was, want in de daaropvolgende jaren kreeg dat grote invloed op de verdere ontwikkeling van de Bond van Bioscooptheater-Directeuren en haar directe opvolgster, de Nederlandse Bioscoop Bond.

\section{Vorming van de Nederlandsche Bioscoop-Trust}

Je inzetten voor de aaneensluiting van de filmbranche om effectiever in verzet te kunnen komen tegen negatieve overheidsbemoeienis was één ding, met je eigen bedrijf het hoofd boven water houden was een ander. Dat laatste werd in de loop van 1920 voor veel ondernemers in de branche prioriteit nummer één. De conjunctuur sloeg om, het publiek ging minder massaal naar de bioscoop dan voorheen. ${ }^{27}$ Wat het nog erger maakte, waren de hoge huurprijzen die de exploitanten voor de films moesten betalen, in het bijzonder als het ging om de zo gewilde filmproductie uit de vs. Hoe dat kwam, is hierboven al vermeld: de Nederlandse filmimporteurs, te klein en te talrijk om vanuit een sterke positie te kunnen onderhandelen, kregen door de Amerikanen het vel over de oren getrokken en deden vervolgens hetzelfde met hun eigen klanten, de bioscoophouders. Tot die klanten niet meer konden betalen, wat in de loop van I920 steeds vaker voorkwam. ${ }^{28}$ Op dat moment moesten de filmverhuurders iets beters zien te verzinnen. Inspiratie daarvoor zocht 's lands grootste filmimporteur, Loet Barnstijn, in het buitenland. Hij probeerde hetzelfde voor elkaar te krijgen als zijn Amerikaanse handelspartners en dat kwam opnieuw neer op integratie van het filmbedrijf. Alleen ging het nu niet meer om integratie op het niveau van de branche als geheel, maar op het niveau van één onderneming; of liever gezegd van een houdstermaatschappij, die door aandelenbezit een groter aantal Nv's controleerde. Die houdstermaatschappij kreeg de naam Nederlandse Bioscoop-Trust, kortweg 
NBT. De door de NBT gecontroleerde NV's waren bedrijven die zich met één specifiek aspect van het filmbedrijf bezighielden: een filmimport en -verhuurbedrijf, een aantal bioscopen, een filmfabriek voor de productie van Nederlandstalige tussentitels, een drukkerij voor de productie van publiciteitsmateriaal en een bedrijf dat in de aangesloten bioscopen de buffetexploitatie voor zijn rekening nam. Kortom: hier werd hetzelfde recept toegepast dat grote, buitenlandse filmindustrieën reeds veel succes had opgeleverd: verticale integratie. ${ }^{29}$

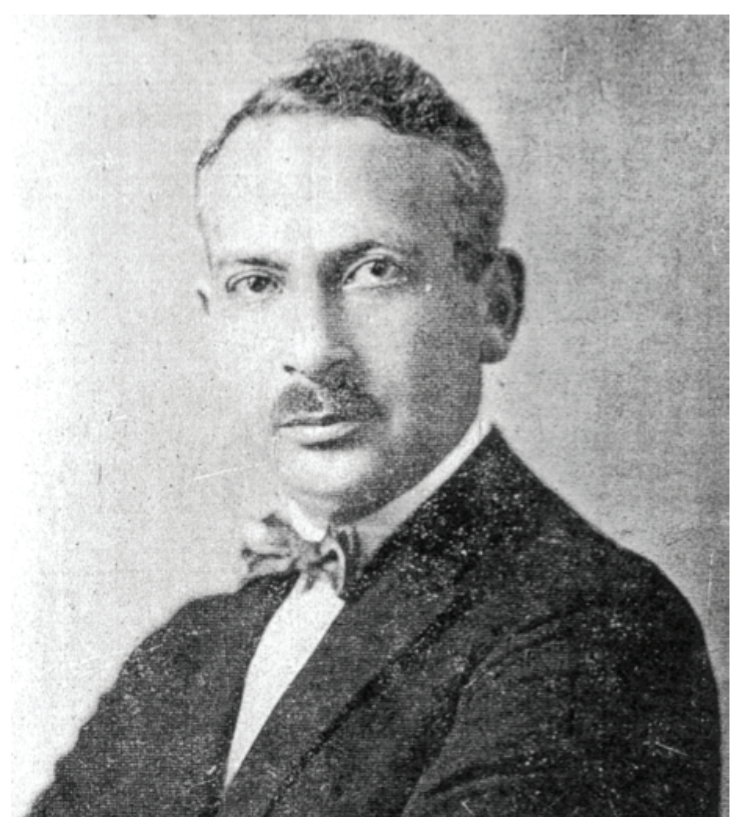

Loet Barnstijn

Bron: NWC, 1 juli 1927

Vergeleken met grote buitenlandse filmbedrijven bleef de NBT nog steeds een kleintje, maar binnen de Nederlandse verhoudingen was het een onderneming 'van geweldigen omvang'. ${ }^{30} \mathrm{Bij}$ de oprichting bedroeg het maatschappelijk kapitaal ruim fl. I0.000.000,- en met tien aangesloten theaters was het in een klap de grootste bioscoopketen van het land. ${ }^{31}$ Wat het prestige van de NBT nog verder vergrootte, was het feit dat een aantal gevestigde namen uit handel en industrie op de lijst van aandeelhouders prijkte, zoals Stokvis (handelsmaatschappij Stokvis \& Zonen), IJssel de Schepper (Koninklijke Stearine Kaarsenfabrief), Onnes van Nijenrode (koffiehandelaar) en niet te vergeten Loet C. Barnstijn himself, een parvenu misschien in dit gezelschap, maar wel de man die zich in de voorafgaande jaren had opgewerkt tot de grootste filmimporteur en -verhuurder in Nederland. Het was zijn Loet C. Barnstijns Film Productions dat als onderdeel van de NBT de filminvoer en distributie ging verzorgen voor de aangesloten bioscopen. ${ }^{32}$ Dit opereren in Trust-verband leverde kostenbesparingen op, waardoor Barnstijn meer te besteden kreeg dan andere verhuurders en zo de beste contracten met onder andere de Amerikaanse filmleveranciers voor hun neus kon wegkapen. Bioscoopexploitanten die hiervan optimaal wilden meeprofiteren, werden opgeroepen hun bedrijven óók onder te brengen in de Trust. Hoe groter de keten, hoe groter het economy-of-scales effect zou worden en hoe meer geld er voor de deelnemers in de Trust te verdienen viel. Dat was althans het verhaal dat de NBT aan de man bracht. ${ }^{33}$ 
In de praktijk pakte het heel anders uit, maar begin I92I, toen de oprichting van de NBT bekend gemaakt werd, zag het er allemaal heel veelbelovend uit en kreeg Barnstijn van vele zijden lof toegezwaaid voor zijn initiatief.

\section{De Directeurenbond in het offensief}

Al was Barnstijn de initiatiefnemer en het boegbeeld van de NBT, hij opereerde zeker niet alleen. Naast prestigieuze investeerders van buiten de filmbranche schaarden zich ook enkele collegafilmondernemers aan zijn zijde. Samen met Barnstijn vormden Elias Viskoper Szn., een Haagse bioscoopexploitant en accountant, en de koopman Johannes Marinus Franke, eveneens uit Den Haag, de Raad van Beheer van de Trust. Daarnaast was er ook nog een Raad van Advies. Een van de leden daarvan werd David Hamburger jr., de man met wie Barnstijn aanvankelijk samen in het bestuur van de Bond van Exploitanten van Nederlandsche Bioscooptheaters had gezeten en die hem begin I9I9 was opgevolgd als vice-voorzitter. Hamburger was vanaf het prille begin betrokken bij de oprichting van de NBT. Hij verkocht zijn Utrechtse Rembrandt Theater aan de Trust en ontving daarvoor onder andere een flink aandelenpakket in de nieuwe onderneming. De afspraken daarover werden al gemaakt vóór I december I920, ruim voordat de oprichting van de Trust bekend werd. ${ }^{34}$ En toevallig of niet, meteen daarop begon Hamburger, die zeker na het vertrek van Nöggerath en Barnstijn de drijvende kracht was binnen het bestuur van de Exploitantenbond, óók binnen het kader van die bond weer heel hard zijn best te doen om de integratie van het Nederlandse filmbedrijf te bevorderen en daarbij de machtspositie van de bond wezenlijk te versterken.

Het eerste doelwit van dit offensief was de al eerder aangestipte eigen filmbeurs van de Rotterdamse bioscoopexploitanten. Begin januari I92I verklaarden Hamburger en de overige leden van het bondsbestuur in het vakblad Kunst en Amusement dat de filmverhuurders voorlopig nog wel zouden verschijnen op de Rotterdamse filmbeurs, maar dat dit op den duur niet zo kon blijven. Waarom dat niet kon, werd in de verklaring niet expliciet uitgelegd, maar de goede verstaander kon het er wel uit opmaken. In de verklaring stond namelijk dat de Vereeniging van Filmverhuurkantoren en de Exploitantenbond voornemens waren samen deel te gaan uitmaken van een nieuw te vormen organisatie. Binnen die nieuwe organisatie zouden voor verhuurders en exploitanten nog wel afzonderlijke afdelingen bestaan, maar het centrale bestuur zou voortaan de belangen van alle ondernemers in het filmbedrijf gaan behartigen. 'De exploitanten van het geheele land en de verhuurders [stonden] naast elkaar' en - zo werd er aan toegevoegd - in dat licht moesten de Rotterdammers nog maar eens goed bedenken hoe lang ze hun afscheidingskoers wilden volhouden. ${ }^{35}$ Dit kwam neer op een verhuld dreigement: een bondsbestuur dat óók de verhuurders vertegenwoordigde, kon veel effectiever dan voorheen de Rotterdamse exploitanten treffen met een filmboycot. Van zo'n boycot was een half jaar eerder al sprake geweest naar aanleiding van het conflict met de Rotterdammers over contributiebetaling. Toen hadden bestuursleden van de verhuurdersvereniging met tijdige bemiddeling escalatie nog weten te vermijden. Nu de Vereeniging van Filmverhuurkantoren echter haar zelfstandigheid opgaf, zou het bestuur van de nieuw te vormen koepelorganisatie - net als de NBT een soort holding dus! - het boycotwapen veel makkelijker kunnen inzetten. ${ }^{36}$

Het klonk dreigend, maar tegelijk was de verklaring van Hamburger in januari I92I voor een 
deel nog bluf. Want hoewel het bondsbestuur voorgaf te spreken namens 'de exploitanten van het geheele land' was dat niet waar. Zoals eerder opgemerkt: in I920 waren nog lang niet alle Nederlandse bioscoopdirecties aangesloten bij de Exploitantenbond. Wilde de nieuwe koepelorganisatie de legitimiteit en de machtsbasis hebben om ook echt te kunnen waarmaken wat het bestuur van de Exploitantenbond begin januari I92I in het vooruitzicht stelde, dan was het zaak het ledenaantal zo snel mogelijk verder te doen groeien. Om dit voor elkaar te krijgen, moesten Hamburger cum suislaten zien dat bioscoopondernemers werkelijk iets aan de landelijke Exploitantenbond hadden. Belangrijk was vooral om die ondernemers te overtuigen, die lokaal opereerden in kleinere plaatsen waar de bioscoop-en amusementssector zo' $\mathrm{n}$ beperkte omvang had, dat er nooit een even krachtige lokale belangenorganisatie als bijvoorbeeld die in Rotterdam zou kunnen ontstaan. Zulke lokale dreumesen hadden wel degelijk óók hun problemen, in het bijzonder met de filmkeurings- en belastingpolitiek van plaatselijke overheden. Maar zo lang de landelijke brancheorganisatie niet echt voor hen in het strijdperk trad, hadden zij geen andere optie dan met pappen en nathouden de lokale autoriteiten zover tegemoet te komen, dat die omgekeerd ook hen nog in staat zouden stellen om als bioscoopexploitant hun brood te blijven verdienen. Lid worden van de landelijke bond was onder deze omstandigheden voor de desbetreffende groep ondernemers weinig urgent. Tot dit inzicht moet eind I920, begin I92I ook het bestuur van de Bond van Bioscooptheater-Directeuren (voorheen de Exploitantenbond) zijn gekomen, dat nu juist was samengesteld uit ondernemers die al gewend of - zoals NBTparticipant Hamburger - van plan waren nadrukkelijk op een bovenlokaal niveau te opereren. ${ }^{37}$

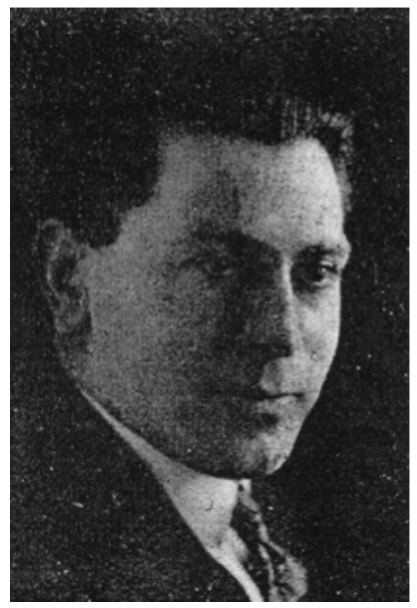

Andre de Jong.

Bron: NWC, 4 mei 1928

Het effect van dit voortschrijdend inzicht werd merkbaar in maart I92I, toen de bond besloot twee Venlose bioscoopdreumesen te hulp te schieten, die ruzie hadden met de plaatselijke autoriteiten. Aanleiding tot die ruzie was een door de gemeente per 3I januari I92I opgelegde verhoging van de vermakelijkheidsbelasting van 20 naar 30 procent van de bruto recettes. Het was de zoveelste in een reeks van voor de plaatselijke bioscopen ongunstige maatregelen. De getroffen ondernemers besloten de tegenaanval in te zetten door de toegangsprijzen van 
hun theaters te verhogen met een percentage dat veel hoger lag dan de belastingmaatregel rechtvaardigde. Niettemin verklaarden de beide exploitanten dat zij wel degelijk door de belastingverhoging waren gedwongen tot hun nieuwe prijspolitiek, waarvan ze vreesden dat deze het geregelde bioscoopbezoek voor menig inwoner van Venlo onbetaalbaar zou maken en daarmee tot de ondergang van hun theaters zou leiden. De hoop was ongetwijfeld dat de gemeente onder druk van deze stemmingmakerij de belastingverhoging zou terugdraaien. De gemeente gaf echter geen krimp, ook niet toen duidelijk werd dat de bezoekersaantallen inderdaad fors afnamen. Normaliter zouden de Venlose bioscoopexploitanten zich nu al snel hebben moeten schikken naar het onvermijdelijke: hun prijzen verlagen en de facto de belastingverhoging accepteren. Door ingrijpen van de landelijke bond liep het echter anders: per 25 maart gingen beide bioscopen dicht en ontvingen de exploitanten - allebei al vanaf het begin aangesloten bij de Directeurenbond - financiële steun uit de weerstandskas. Bovendien werd de RoomsKatholieke Werkliedenvereniging, die in Venlo een eigen bioscoop exploiteerde en vanwege haar status van besloten vereniging géén vermakelijkheidsbeasting hoefde te betalen, getroffen door een van bondswege opgelegde filmboycot. Toen deze verenigingsbioscoop probeerde die boycot te ontduiken door films uit Duitsland te betrekken, toog onmiddellijk een bondsdelegatie naar Düsseldorf om de film draaiende Werklieden zelfs buiten de landsgrenzen succesvol de pas af te snijden. De bondsdelegatie wist van de Duitse collega's de belofte los te krijgen, dat ze geen zaken meer zouden doen met het van de Nederlandse bondskudde afgedwaalde schaap. Via het hier voor het eerst daadwerkelijk ingezette boycotwapen werden zo alle lokale bioscopen gedwongen één front te vormen bij de sluitingsactie, zelfs als ze opereerden als besloten vereniging. ${ }^{8}$

Ongeveer gelijktijdig met deze Venlose affaire ontstond een zelfde soort conflict in Hilversum. Begin maart I92I probeerde het gemeentebestuur ook hier haar verontrustend lege kas te spekken door de vermakelijkheidsbelasting fors te verhogen. In dit geval ging het zelfs om een verdubbeling van 20 procent naar 40 procent van de bruto opbrengst. Het vakblad Kunst en Amusement sloeg groot alarm en de Directeurenbond ging ook hier tot actie over om aan de leden haar slagvaardigheid te tonen. ${ }^{39}$ Een bestuursdelegatie klopte aan bij de Hilversumse burgemeester, die echter vasthield aan de geplande belastingverhoging. De bondsbestuurders stuurden vervolgens een nauwelijks verhuld dreigement aan de raad. Als de belastingverhoging doorging zouden de Hilversumse bioscopen onherroepelijk sluiten..$^{\circ}$ Desondanks besloot de raad met ruime meerderheid tot de gewraakte belastingverhoging. Prompt meldde Kunst en Amusement op 25 maart I92I dat de Hilversumse bioscopen met onmiddellijke ingang hun deuren hadden gesloten. Andere instellingen van vermaak in Hilversum toonden zich solidair. Concerten en sportevenementen werden afgelast om het gemeentebestuur verder onder druk te zetten. Geen bioscoophouder kon er nu nog aan twijfelen: de landelijke Directeurenbond nam het óók op, in woord en daad, voor de kleine bedrijven in de provincie.

\section{De Nederlandsche Bioscoop Bond opgericht en al snel in de problemen}

Terwijl de bioscoopsluitingen in Venlo en Hilversum voortduurden, werd op I8 juli I92I bewaarheid wat het bestuur van de Bond van Bioscooptheater-Directeuren begin januari van dat jaar had aangekondigd: bioscoopexploitanten en filmverhuurders lieten hun brancheorganisaties fuseren. De fusie kreeg haar beslag tijdens een vergadering in het Flora Theater in Amsterdam. 
De Bond van Bioscooptheater-Directeuren, waarvan voortaan zowel exploitanten als verhuurders (en ook de weinige fabrikanten) lid zouden zijn, ging verder onder een nieuwe naam Nederlandsche Bioscoop Bond (NBB) - én een nieuwe voorzitter. Mullens maakte in die rol plaats voor D. Hamburger jr. en het nieuwe hoofdbestuur zou voortaan bestaan uit vifftien leden, met een dagelijks bestuur van vijf leden. Dat dagelijks bestuur bestond overigens grotendeels uit ondernemers die ook al in het 'oude' bestuur zaten. De leden-exploitanten van de Bond werden verdeeld in acht plaatselijke afdelingen, echter voorlopig zonder aparte gezamenlijke exploitantenonderafdeling als tegenhanger van de onderafdeling voor verhuurders. ${ }^{4 \mathrm{I}}$ Daardoor was de reorganisatie in feite niet meer dan het onderbrengen van de verhuurdersvereniging als afdeling binnen de Exploitantenbond, terwijl was aangekondigd dat er een koepelorganisatie zou komen met daarbinnen aparte afdelingen voor zowel verhuurders als exploitanten, wat weer impliceerde dat beide afdelingen en de koepel ook aparte besturen zouden krijgen, met het bestuur van de koepel als eindverantwoordelijke. Nog jarenlang bleef het niet tot stand komen van een eigen afdeling voor exploitanten een bron van spanning binnen de NBB. Het was niet de enige. Integendeel. Al snel en in het bijzonder vanaf begin I923 stapelde zich de ene kwestie op de andere, met als resultaat dat het de NBB voorlopig niet anders verging dan voorheen de Nederlandsche Bond van Exploitanten van Bioscooptheaters: na een voortvarende start verloor de organisatie aan daadkracht en legitimiteit.

Aan de basis van de vele problemen en conflicten waarmee de NBB te kampen kreeg, lag een drietal factoren. Ten eerste was er het al genoemde feit dat begin jaren twintig nog niet alle bioscoopondernemers en filmverhuurders in Nederland bij de bond waren aangesloten. Vooral het afzijdig blijven van een flink deel van de Rotterdamse bioscoopexploitanten was een probleem. Al jarenlang waren zij op lokaal niveau georganiseerd in hun Vereeniging van Directeuren van Publieke Vermakelijkheden, waarvan naast bioscoopondernemers óók directeuren van andersoortige amusementsbedrijven deel uitmaakten. Daarmee bleef naast de alleen voor filmondernemers toegankelijke NBB een breder georiënteerd alternatief voor organisatie en belangenbehartiging van de bioscoopbranche voorhanden. Nog vervelender was dat de Rotterdamse afzijdigheid ook nog eens de concrete politiek ondermijnde die de NBB intern voerde om haar eigen positie te versterken. De acties waarmee de bond in Venlo en Hilversum haar vermogen demonstreerde om op een effectieve manier het boycot- en sluitingswapen te hanteren, vormden één onderdeel van die politiek. Een tweede onderdeel bestond uit het ontwikkelen van regels en procedures, gericht op het sturen en standaardiseren van het zakelijke verkeer tussen filmverhuurders en bioscoopexploitanten in Nederland. Een eerste stap in die richting was de al eerder genoemde instelling in januari I92I van een geschillencommissie voor het oplossen van zakelijke conflicten tussen filmverhuurders en bioscoopondernemers geweest. In maart I923 volgde een tweede belangrijke stap met het invoeren van de zogenaamde 'Bondsvoorwaarden' door de geschillencommissie voor alle bij de NBв aangesloten bedrijven..$^{42}$ In feite ging het hierbij om een voorloper van het latere standaardcontract voor huurovereenkomsten tussen filmdistributeurs en bioscoopexploitanten. ${ }^{43}$ Alle bij de Nвв aangesloten filmverhuurders - en alle belangrijke verhuurders waren dat - mochten alleen nog maar films leveren volgens de Bondsvoorwaarden. Dat was geen probleem zolang de huurders óók nBв-leden waren. Een flink aantal Rotterdamse bioscoopexploitanten was dat echter niet, terwijl ze voor de filmverhuurders wèl interessante klanten waren. Het gevolg was dat filmverhuurders de Bondsvoorwaarden 
ontdoken als ze zaken deden met niet bij de NBв aangesloten Rotterdammers. Toen eind I923 één zo'n geval bekend werd en de boosdoener - de firma Pathé - daarvoor bij het Nвв-hoofdbestuur op het matje werd geroepen, kwam Pathé met een contract op de proppen dat haar Rotterdamse klant eerder had afgesloten met een andere filmleverancier. Ook in dat contract stond expliciet vermeld dat de Bondsvoorwaarden er niet op van toepassing waren. Veel pikanter echter was het feit dat de directeur van het betrokken filmverhuurbedrijf - HAP - nota bene lid was van hetzelfde NBB-hoofdbestuur, dat Pathé voor ontduiking van de Bondsvoorwaarden ter verantwoording riep. Dat dit de geloofwaardigheid van het Nвв-bestuur niet ten goede kwam, spreekt voor zich.

Het genoemde voorval leidt ons naar de tweede factor die de NBB begin jaren twintig voortdurend in de problemen bracht. Die tweede factor laat zich kort karakteriseren als de 'NBBNBT-Barnstijn connectie'. Tussen de Bioscooptrust en de NBв bestonden verdacht veel personele verbindingen. We zagen dat al eerder gedemonstreerd in de figuur van David Hamburger junior, de man die naast NBB-voorzitter ook grootaandeelhouder van de NBT en dus zakenpartner van Loet Barnstijn was. Nu wil het geval dat de HAP-directeur en NBB-bestuurder die bij het akkefietje met Pathé rondom de ontduiking van de Bondsvoorwaarden dubbel spel speelde, Loet Barnstijns broer Eduard was. Zulke verbindingen tussen de top van de NBB en die van de NBT waren er nog wel meer. Een ander NBB-bestuurslid, Johannes Marinus Franke, maakte deel uit van de NBT-directie en bovendien waren zowel Hamburger als Franke lid van de NвBgeschillencommissie. In die laatste hoedanigheid waren zij mede verantwoordelijk voor het instellen van een verbod op het leveren van films aan bioscooptheaters die achterliepen met het betalen van filmhuren. Uitgerekend het verhuurbedrijf van de Trust bleek echter herhaaldelijk toch films te blijven leveren aan zulke, door een boycot getroffen bioscopen, zonder dat de NвB geschillencommissie daar verder tegen optrad. Zo kon makkelijk de indruk ontstaan dat de NBB in plaats van belangenvertegenwoordiger van de hele Nederlandse filmbranche te zijn, op verhulde wijze vooral de belangen diende van de NBT en daarmee dit concern hielp haar positie in de Nederlandse markt te verbeteren ten koste van de overige, al dan niet bij de NBB aangesloten bedrijven.

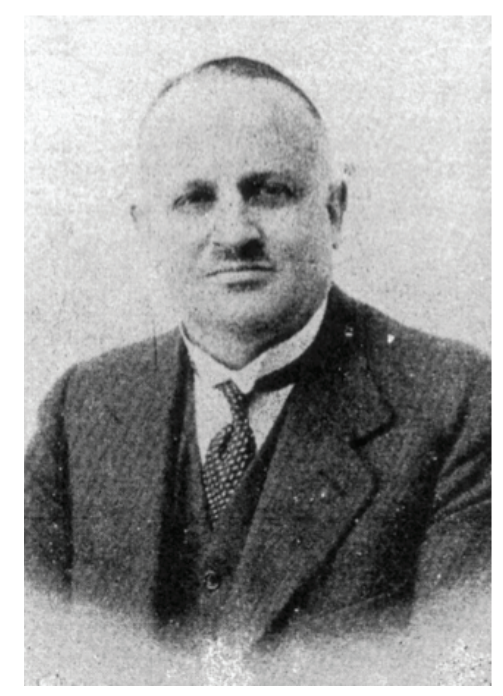

Eduard Barnstijn

Bron: NWC, 4 mei 1928 
De derde factor die tijdens de eerste helft van de jaren twintig de positie van de NBB stelselmatig onder druk zette, was het optreden van bondslid Nathan Heyman Wolf. Deze Wolf, exploitant van de Amsterdamse Jeugdbioscoop en publicist, werd in 1922 hoofdredacteur van Kunst en Amusement, het hier al eerder genoemde vakblad voor het bioscoopbedrijf. ${ }^{44}$ Kunst en Amusement functioneerde in de jaren rond 1920 onder andere als forum voor discussies over de vraag hoe de organisatie en belangenbehartiging van de Nederlandse filmbranche nu het best kon worden aangepakt. Wolf had hierover zelf zeer uitgesproken opvattingen. Hij had al in september 1920 samen met de Amsterdamse jurist mr. Fr.A. Kokosky bij het bestuur van de toen nog niet met de filmverhuurders verenigde Bond van Bioscooptheater-Directeuren een voorstel ingediend om dit vraagstuk op te lossen. Wolf en Kokosky stond de vorming van een landelijke federatie voor ogen, met daarbinnen vier afzonderlijke verenigingen van bioscoopexploitanten: één in Amsterdam, één in Rotterdam, één in Den Haag en een vierde vereniging voor 'de provincie'. Desgewenst zou ook nog een afzonderlijke vereniging van filmverhuurders binnen de federatie een plaats kunnen krijgen. Elk van de aangesloten verenigingen zou bestuurlijk en financieel haar autonomie behouden ten opzichte van het bestuur van de federatie, die slechts een platform zou bieden voor samenwerking tussen de vier, eventueel vijf aangesloten verenigingen. In dit model zouden besluiten over het boycotten of sluiten van bedrijven niet op het federale, maar op het plaatselijke of provinciale niveau worden genomen en worden betaald uit op datzelfde niveau te vormen weerstandskassen. Een laatste aspect van het voorstel was dat in de verenigingen en de federatie alleen plaats zou zijn voor ondernemers uit de filmbranche, niet voor directeuren van andersoortige publieke vermakelijkheden. ${ }^{45}$

Met hun voorstel formuleerden Wolf en Kokosky in september 1920 zoiets als een derde weg tussen enerzijds het model van een sterk gecentraliseerde, landelijke brancheorganisatie voor het filmbedrijf en anderzijds het Rotterdamse model, dat niet exclusief op filmondernemers gericht was en waarin bovendien de meeste zeggenschap op het plaatselijke of hooguit regionale niveau lag en bleef liggen, ook als de plaatselijke of regionale organisaties onderling samenwerkten. Het bestuur van de Bond van Exploitanten van Nederlandsche Bioscooptheaters koos in het najaar van I920 niet de door Wolf en Kokosky voorgestelde oplossing, maar opteerde voor een sterk gecentraliseerd model, waaraan de Nederlandsche Bioscoop Bond concreet gestalte moest geven. Wolf bleef echter zijn alternatieve visie koesteren en schreef daarover in Kunst en Amusement. Aanvankelijk deed hij dat slechts af en toe en op gematigde toon, ${ }^{46}$ maar medio I923 werd dat radicaal anders. Deze omslag had twee achtergronden. Ten eerste boekte de Rotterdamsche Vereeniging van Directeuren van Publieke Vermakelijkheden in mei I923 na een maandenlange publiciteits- en lobbycampagne succes in haar strijd tegen de hoge vermakelijkheidsbelasting. De gemeenteraad verlaagde het tarief. Wolf presenteerde dit succes van de Rotterdammers in Kunst en Amusement als het onomstotelijke bewijs dat een lokaal opererende belangenvereniging effectiever was dan de gecentraliseerde, landelijk opererende NBB en begon opnieuw vurig te pleiten voor herstructurering van de NBB volgens het model dat hij en Kokosky in september 1920 al eens hadden gelanceerd. 47

Ongetwijfeld maakte Wolf zich hiermee bij het Nвв-bestuur niet geliefd, maar nog beroerder werden de verhoudingen toen hij een paar weken later in Kunst en Amusement bioscoophouders waarschuwde de film LA GARÇONNE (Frankrijk, I923) niet te huren, omdat deze vanwege zijn immorele inhoud in Amsterdam was afgekeurd en daarmee door andere plaatselijke 
keuringscommissies evenmin geaccepteerd zou worden. Wolf bleek voor zijn beurt te hebben gesproken. De Amsterdamse filmkeurders moesten de film nog gaan zien toen Wolf schreef dat ze hem al hadden verboden. Natuurlijk had de NBв geen enkele formele zeggenschap over wat Wolf in Kunst en Amusement schreef, maar toch voelde het bondsbestuur zich geroepen om Wolf te laten opdraven en hem de mantel uit te vegen, omdat hij de belangen van Nederlandse filmbedrijf zou hebben geschaad door de importeur van de film moedwillig te duperen. Wolf was des duivels en trok vervolgens weken achtereen in Kunst en Amusement fel van leer tegen het Nвв-bestuur, dat hem uiteindelijk als bondslid royeerde. Wolf schreef echter verbeten door, waarbij hij gretig alle incidenten uitbuitte die de schijn wekten dat het NBв-bestuur en de NвBgeschillencommissie in feite een verlengstuk waren van Loet Barnstijn en zijn Nederlandsche Bioscoop Trust. Een tweede aambeeld waarop Wolf naar hartenlust hamerde, was de vermeende incompetentie die het Nвв-bestuur aan de dag legde in de wijze waarop het zich mengde, of liever gezegd helemaal niet mengde, in het nog steeds lopende politieke debat over de invoering van een landelijke bioscoopwet. In het kader van zijn campagne tegen het NBв-bestuur begon Wolf bovendien serieus te werken aan de vorming van een alternatieve brancheorganisatie, gebaseerd op het eerder door hem en Kokosky ontworpen model, waarvoor - zo leek het - vooral een aantal Amsterdamse NBв-leden nu wel wat voelde.

Het NBB-bestuur kreeghetknap lastig metdeze ontwikkelingen, zelfs alleek heter aanvankelijk even op dat de Rotterdammers na hun zege in de strijd tegen de vermakelijkheidsbelasting de Bond tegemoet wilden komen. Een vijftal, tot dan toe afvallige Rotterdamse directies liet midden december 1923 weten het lidmaatschap van de NBB nu wel te ambiëren. $4^{8}$ Volgens Wolf deden zij dit vanuit de verwachting dat zij op grond van hun nieuw verworven overwinnaarstatus het gezag zouden hebben om de bond van binnenuit te hervormen. Inderdaad werden de vijf betreffende directies kort daarop bondslid en één van de heren uit dit gezelschap - Carel van Zwanenburg, directeur van het Luxor Theater en voorzitter van de Rotterdamsche Vereeniging van Directeuren van Publieke Vermakelijkheden - werd vervolgens midden april I924 gekozen tot lid van de geschillencommissie. Binnen de gelederen van de квв bleef Van Zwanenburg zich echter voortdurend namens zijn Rotterdamse achterban manifesteren met voorstellen en commentaren die tegen het beleid van het Bondsbestuur ingingen, met als gevolg dat de positie van dit college na de toetreding van de Rotterdammers er toch niet sterker op werd.

David Hamburger, voorzitter van het NBB-hoofdbestuur, kreeg kennelijk tabak van al het gedoe en maakte in januari I925 aanstalten zijn functie neer te leggen. Een maand later kwam hij echter terug op dat besluit, hiertoe aangespoord door een deel van de NBB-leden en vermoedelijk ook nieuwe moed puttend uit het feit dat Loet Barnstijn hem en zijn bestuur publiekelijk te hulp schoot. In het Nieuw Weekblad voor de Cinematografie (NWC), een met Wolfs Kunst en Amusement concurrerend vakblad voor de filmbranche, publiceerde Barnstijn een serie artikelen waarin hij de verdiensten van het NBB-bestuur breed uitmat en de criticasters van de bond onder vuur nam. Bovendien startte Barnstijn via hetzelfde NWC een publiciteitscampagne om in de aanloop naar de eerstvolgende Algemene Ledenvergadering zo veel mogelijk niet-leden zo ver te krijgen dat zij zich alsnog als NBв-lid aanmeldden. Een serie ingezonden brieven in het NWC suggereerde dat Barnstijns ledenwervingscampagne succes had en dat er voor de NBB eindelijk betere tijden zouden aanbreken. De diepste crisis moest toen echter nog komen. 


\section{De NBB op het nippertje gered door Hamburger senior en de Haagse politiek}

Eigengereide Rotterdammers, de pen van Nathan Wolf en de verdenking niet meer dan een stel zetbaasjes van de Nederlandsche Bioscoop Trust te zijn, al die plagen waaronder David Hamburger jr. en zijn мвв-bestuur in de vroege jaren twintig gebukt gingen, voegden zich in maart en april I925 nog één keer samen in een enorme rel waar de Bioscoopbond bijna aan ten onder ging. Directe aanleiding tot het uitbreken van die rel was een reclamestunt van Leonardus Lorjé, een zwager van David Hamburger en sinds eind januari I925 namens de Nederlandsche Bioscoop Trust directeur van het Scala bioscooptheater in Rotterdam. In een pamflet liet Lorjé het plaatselijke bioscooppubliek op schampere toon weten dat hij de prijzen van het Scala Theater fors had verlaagd, om zich zo positief te onderscheiden van de andere bioscoopdirecties in de stad, die hun klanten schandelijk zouden uitmelken door de prijzen onnodig hoog te houden. De plaatselijke bioscoophouders waren laaiend en klaagden Lorjé onmiddellijk aan bij het hoofdbestuur van de Bioscoopbond. Dat sprak zijn afkeuring uit over het pamflet van Lorjé, maar koos uit de drie mogelijke vormen van bestraffing - een filmboycot, een boete of een waarschuwing - voor de laatste en lichtste optie. Lorjé's Rotterdamse concurrenten wisten niet wat ze hoorden. Ze interpreteerden het slappe bondsoptreden als het definitieve bewijs dat de NBв in feite gedomineerd werd door vertegenwoordigers van de Trust en dit bedrijf daarom stelselmatig voortrok. Alle Rotterdamse directies dreigden uit de bond te zullen stappen als het hoofdbestuur niet onmiddellijk alsnog het Scala Theater via een boycotmaatregel voor minimaal een week zou sluiten. Verder dienden ze tijdens de algemene ledenvergadering van de NBB op 30 maart 1925 een motie van wantrouwen in tegen het zittende hoofdbestuur. Het bestuur overleefde de motie, zij het met een meerderheid van slechts één stem. ${ }^{49}$ De commotie hield echter aan, onder andere omdat een deel van de voorstemmers op het moment van de stemming officieel nog geen NBB-lid was en dus nog helemaal geen stemrecht had. Ondernemers die er zelf helemaal niet bij waren geweest, kregen het gebeuren toch nog mee via de vakpers. In Kunst en Amusement had Wolf de Scala-affaire al vanaf het eerste begin uitvoerig en met veel stemmingmakerij tegen NBB en NBT verslagen. Na de tumultueuze ledenvergadering rolden de diverse partijen ook in het rivaliserende vakblad NWC heftig bakkeleiend over elkaar heen..$^{\circ}$ Het hoofdbestuur zag er intussen geen gat meer in, belegde een tweede algemene ledenvergadering op 27 april I925 en trad bij die gelegenheid voltallig af, zonder dat er zelfs maar kandidaten waren voor een nieuw te vormen bestuur. De NBB was op sterven na dood.

Dat de NBв die $27^{\mathrm{e}}$ april I925 toch nog overleefde, dankte de bond aan David Hamburger senior, bioscoopondernemer in Amsterdam en geen familie van de afgetreden voorzitter David Hamburger junior. Hamburger senior nam het woord, maande de strijdende ondernemers om voor de algemene zaak hun persoonlijke opvattingen opzij te zetten en diende een motie in, die erop aanstuurde het NBB-bestuur zodanig te hervormen dat een belangenverstrengeling tussen de bondsleiding en de NBT of enig ander bedrijf in de toekomst uitgesloten zou zijn:

'Het is voor den gang van zaken gewenscht, dat het Hoofdbestuur in het vervolg uit ten hoogste negen personen bestaat en dat in het Hoofdbestuur, [...] van iedere zaak of combinatie van zaken niet meer dan één persoon zitting kan nemen, alsmede dat van dat college evenmin bloedverwanten tot in den tweeden graad kunnen behoren. ${ }^{5 r}$ 


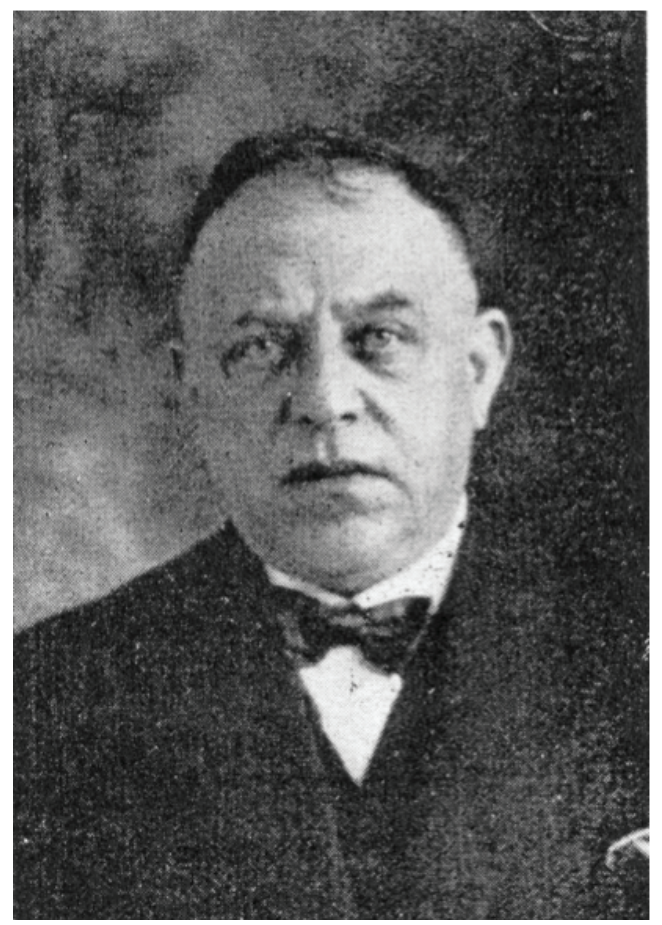

David Hamburger Sr

Bron: NWC, 4 mei 1928

In zijn motie verzocht Hamburger senior verder het hoofdbestuur terug te komen op zijn collectieve ontslagname en sprak het vertrouwen uit dat dit hoofdbestuur rekening zou willen houden met de 'vorengemelde wensen van de vergadering. ${ }^{52}$ Er klonken nog wel enige stemmen van protest tegen deze motie, maar uiteindelijk werd ze toch met algemene stemmen aangenomen. Het hoofdbestuur was echter niet meteen blij, beledigd als het zich voelde door de eerdere gang van zaken. Het verlangde dat de leden zich nogmaals zouden uitspreken middels een ondubbelzinnige motie van vertrouwen, ditmaal niet gekoppeld aan de voorwaarde inzake bloedverwantschap en ook zonder de suggestie dat 'het Hoofdbestuur een H.A.P.-N.B.T.-combinatie is'.53 $\mathrm{Na}$ het nodige gemor en heen en weer gepraat kwam zo'n motie in stemming. 66 leden stemden voor, 4I tegen en ig stemden blanco. Maar voor het hoofdbestuur was dat voldoende om te besluiten tot aanblijven. Voor half mei werd nu een bestuursverkiezing uitgeschreven om tegemoet te kunnen komen aan de in de motie geformuleerde richtlijnen met betrekking tot de bestuurssamenstelling.

Stel, de NBB was in april I925 wèl ten onder gegaan. Zou er dan een nieuwe brancheorganisatie van het Nederlandse filmbedrijf zijn ontstaan met een meer federatieve structuur, grofweg georganiseerd langs de lijnen die eerder door Wolf en Kokosky waren voorgesteld en ook heel dicht in de buurt kwamen van wat de tot eind I923 nog niet bij de bond aangesloten bioscoopondernemers uit Rotterdam voor ogen stond? In zo'n structuur zou de machtsbalans tussen enerzijds het plaatselijke en eventueel regionale organisatieniveau en anderzijds het op landelijk niveau te vormen federatiebestuur ongetwijfeld sterker in het voordeel van dat eerste 
niveau zijn uitgevallen. Toch zou op den duur die balans waarschijnlijk weer meer ten gunste van het federatieniveau zijn bijgesteld. Immers, al in april I925 waren bepaalde feiten en ontwikkelingen waarneembaar, die er op duidden dat een effectief verzet van de branche tegen de belasting- en censuurpraktijken van diverse overheden op het lokale of regionale niveau niet te realiseren was. Het door de Rotterdammers in I923 op lokaal niveau geboekte succes in de strijd tegen de vermakelijkheidsbelasting was namelijk in de tussentijd alweer volledig tenietgedaan. Nadat bij de Gemeenteraadsverkiezingen van mei I923 de confessionelen hun positie in de Rotterdamse Raad versterkten en een rechts college in het zadel hielpen, waren diezelfde confessionelen er als de kippen bij om de verlaging van de vermakelijkheidsbelasting weer ongedaan te maken. Het duurde een jaar voordat ze hun zin kregen, maar eind mei I924 werd het oude, hoge tarief van twintig procent hersteld en was de Rotterdamsche Vereeniging van Directeuren van Publieke Vermakelijkheden weer terug bij af. ${ }^{54}$ Dat haar model van lokale belangenbehartiging beter zou zijn dan het op nationaal niveau gecentraliseerde NBB-model, viel daarna onmogelijk meer vol te houden. Bovendien waren er de ontwikkelingen op het Haagse front. Sinds I9ı8 lag de invoering van een nationale bioscoopwet en dus van een landelijke regeling van de filmkeuring in het verschiet. Weliswaar had een eerste wetsvoorstel daartoe begin maart 1923 schipbreuk geleden in de Tweede Kamer, maar daarmee was de inzet om het 'bioscoopvraagstuk' op nationaal niveau te regelen nog niet van de baan. Sterker, op 20 april I925 - een week voor het collectieve aftreden van het NBв-bestuur - liet een Kamermeerderheid bij motie vastleggen dat de behandeling door de Tweede Kamer van een nieuw ontwerp voor een bioscoopwet nog vóór het zomerreces moest plaatsvinden. Dat zette voor de filmondernemers druk op de ketel en maakte van het aftreden van het Nвв-bestuur op 27 april een des te dramatischer gebaar. Het is zelfs denkbaar dat het bestuur met zijn aftreden de plotseling in Den Haag ontstane situatie willens en wetens uitspeelde: hoe intenser de crisissfeer, hoe groter de kans dat de protesterende achterban toch nog zou inbinden om erger te voorkomen. De Kamer bleek uiteindelijk haar ambities niet te kunnen waarmaken en kwam pas in het nieuwe parlementaire jaar toe aan de Bioscoopwet, maar dat kon eind april I925 nog niemand voorzien. En dus moeten filmondernemers in Nederland zich op dat moment hebben afgevraagd wie er nu op korte termijn voor hen in Den Haag moest gaan lobbyen, als de Bond zichzelf onthoofdde? In die context zullen nog maar weinigen moeite hebben gehad met het concept van een sterke, landelijk gecentraliseerde bioscoopbond. Een zich krachtig manifesterende belangenorganisatie was juist gevraagd, nu slag moest worden geleverd in de Haagse arena, waar de confessionelen de meerderheid hadden en vooral de Anti-Revolutionairen onder hen het bioscoopvermaak liever kwijt dan rijk waren. Als er eind april I925 voor Nederlandse filmondernemers nog reden was om zich te verzetten tegen de Nвв als landelijke brancheorganisatie, dan kon dat er eigenlijk maar één zijn: het vermoeden dat de NBB aan de leiband liep van de NBT en er in feite op uit was om hun concurrentiepositie ten opzicht van de Trust zo veel mogelijk te verzwakken. Dat het intussen met de NBT maar zo-zo ging en de onderneming zeker niet de overmachtige speler in het Nederlandse filmbedrijf geworden was die hij aanvankelijk beloofde te worden, maakte daarbij vermoedelijk niet veel uit. ${ }^{55}$ Nog steeds was een van 's lands grootste en machtigste filmdistributiebedrijven, Loet C. Barnstijns Film Productions, onderdeel en in feite het hart van de Trust. Zo lang dat zo bleef, zou een Nвв waartegen de verdenking bestond structureel de Trust te bevoordelen, nooit de legitimiteit en bestuurlijke effectiviteit verwerven die zij behoefde, 
wilde zij echt als de brancheorganisatie van het Nederlandse filmbedrijf worden erkend. Wat dat betreft sloeg Hamburger senior in de ledenvergadering van 27 april I925 de spijker precies op de kop, door in zijn motie de eventuele belangenvervlechting tussen NBB-top en NBT via een bestuurlijk-organisatorische ingreep definitief te blokkeren. Tekenend is dat dit voor alle, bij die ledenvergadering aanwezige ondernemers - inclusief degenen die het felst tegen het zittende квв-bestuur van leer waren getrokken - voldoende was om hen een club overeind te doen houden die er voordien steeds op had ingezet te functioneren als een sterk gecentraliseerde, nationale brancheorganisatie. Daarin lag kennelijk het probleem niet meer; ontvlechting van NBB en NBT was voldoende.

Na de interventie van Hamburger senior en de vervolgens daadwerkelijk doorgevoerde aanpassing en nadere reglementering van de bestuurssamenstelling van de NBB, slaagde de bond er dan ook eindelijk in om haar positie als externe belangenbehartiger en interne regulator van het Nederlandse filmbedrijf te consolideren en uit te bouwen. Vanaf het najaar van I925 voerde het bestuur een deels succesvolle lobby in politiek Den Haag om een nieuw en uiteindelijk ook door beide Kamers aangenomen voorstel voor een landelijke Bioscoopwet op diverse punten aan te passen. Verder had de Bond succes met een aantal plaatselijke acties voor verlaging van de vermakelijkheidsbelasting en initieerde het bestuur een volgende serie wijzigingen van de statuten. Daarbij werd het onder andere mogelijk gemaakt plaatselijke en gewestelijke bondsafdelingen van bioscoopexploitanten op te richten, maar kreeg tegelijkertijd het hoofdbestuur de bevoegdheid ondernemingen van het lidmaatschap uit te sluiten 'wier wijze van zaken doen niet in het belang van het bedrijf wordt geacht'. ${ }^{6}$ Bovendien kwam er een bepaling dat in Nederland films alleen nog verhuurd of verkocht mochten worden tussen bedrijven die lid waren van de NBB. Al deze aanpassingen werden tijdens de ledenvergadering van april I926 met overgrote meerderheid aangenomen en vastgelegd in de statuten van de Bond, waarmee in feite, zoals Dibbets in I985 schreef, 'de hele bedrijfstak onder het regime van de NBB gebracht' was. ${ }^{57}$ Dat de Bond slechts een jaar daarvoor nog langs de rand van de afgrond scheerde en het interne tumult alleen wist te overwinnen uit vrees voor wat er in Den Haag te gebeuren stond, wilde zich nadien niemand meer herinneren.

\section{Noten}

I Bart Hofstede, In het wereldfilmstelsel. Identiteit en organisatie van de Nederlandse film sedert 1945, Eburon, Delft 2000, p. I47-I48.

2 Karel Dibbets, 'Het bioscoopbedrijf tussen twee wereldoorlogen', in: Karel Dibbets \& Frank van der Maden (red.), Geschiedenis van de Nederlandse film en bioscoop tot 1940, Het Wereldvenster, Houten 1986, p. 229-270. Zie verder: J. Th. van Taalingen, Nederlandse Bioscoopbond Go jaar: een documentaire over de Nederlandse bioscoopbond en het daarin georganiseerde film- en bioscoopbedrijf, Nederlandse Bioscoopbond, Amsterdam I978. In deze door de NBB uitgegeven publicatie wordt de oprichting in februari I9I8 van de Bond van Exploitanten van Nederlandsche Bioscooptheaters de directe voorloper van de NBB - als beginpunt van de NBB-geschiedenis opgevat.

3 Ivo Blom, 'Business as usual? Filmhandel, bioscoopwezen en filmpropaganda in Nederland tijdens de Eerste wereldoorlog', in: Hans Binneveld, Martin Kraaienstein, Marja Roholl, Paul Schulten (red.), Leven naast de catastrofe. Nederland tijdens de Eerste Wereldoorlog, Verloren, Hilversum 200I, p. I30; Dibbets, 'Bioscoopbedrijf tussen twee wereldoorlogen', p. 23I-232; André van der Velden \& Judith Thissen, 'Spectacles of conspicuous consumption: picture palaces, war profiteers and the social dynamics of moviegoing in the Netherlands, I9I4-I922', in: Film History, 4, vol. 
22, 2010, p. $455-456$.

4 Ivo Blom, Jean Desmet and the Early Dutch Film Trade, AUp, Amsterdam 2003, p. 232-238; Kunst en Amusement, 9 juli 1920 .

5 Blom, Jean Desmet, p. 25I-276; Ansje van Beusekom, Kunst en amusement. Reacties op film als een nieuw medium in Nederland, 1895-1940, Arcadia, Haarlem 200I, p. 90.

$6 \mathrm{Al}$ in I9I6 constateerde het vakblad De Bioscoop-Courant dat Amerikaanse films steeds gewilder werden bij het publiek en de bioscoopexploitanten; De Bioscoop-Courant, 3 maart I9I6.

7 Kunst en Amusement, 9 juli I920.

8 Dibbets, 'Bioscoopbedrijf tussen twee wereldoorlogen', p. 234-237. De hoge belastingdruk werd vanaf het midden van de jaren tien een steeds vaker terugkerend onderwerp in de film vakbladen.

9 Onno de Wit, 'Pedagogen en zedenmeesters in de greep van het bioscoopkwaad. De Rotterdamse Bioscoopcommissie, I9I3-1928', in: Jaarboek mediageschiedenis, 3, I99I, p. 23. Dat meteen werd samengewerkt met directeuren van variété-theaters was logisch: die vertoonden indertijd vaak films als onderdeel van hun programma's en kregen daarom óók te maken met de plaatselijke filmkeuring.

Io De Kinematograaf, ro oktober I9I3.

II Dibbets, 'Bioscoopbedrijf tussen twee wereldoorlogen', p. 238.

I2 Mirande de Jong, Gids voor Nederlandse filmtijdschriften: van 1912 tot heden, Stichting film en wetenschap, Amsterdam I990; Dibbets, 'Bioscoopbedrijf tussen twee wereldoorlogen', p. 239.

I3 Willem van Lier, 'Een hulpkreet uit het Zuiden', Bioscoop Courant, 8 februari I9I8.

I4 Zijn werkelijke naam was Daniël Hamburger Jzn. maar omdat hij in contemporaine openbare en niet gepubliceerde bronnen steevast wordt aangeduid als David Hamburger Jr. hebben wij die benaming hier ook aangehouden.

I5 Het voorlopig bestuur bestond uit Loet C. Barnstijn (Den Haag), J.G. Ehrenfeldt (Amsterdam), J. Silvius (Dordrecht), L.P.H. de Ridder (Watergraafsmeer), D. Hamburger (Utrecht). De Filmwereld, 2 maart igi8.

I6 Het definitief benoemde bestuur bestond uit Willy Mullens (Den Haag), Loet C. Barnstijn (Den Haag), L. Monnier (Nijmegen; korte tijd later vervangen door R. Minden uit Amsterdam), F.A. Nöggerath (Amsterdam), E. de Hoop (Amsterdam), D. Hamburger Jr. (Utrecht), S. Walvis (Breda). De Filmwereld, I6 maart I9I8.

I7 Binnen het bioscoopbedrijf was Mullens zoiets als een veteraan van het eerste uur. Hij dreef samen met zijn broer Bernard Mullens al een reisbioscoop, nog voordat er in Nederland vaste bioscooptheaters kwamen. Later exploiteerden zij vaste bioscooptheaters in Den Haag en Amsterdam. Willy Mullens werd bij de oprichting van de bond behalve voorzitter meteen ook erelid gemaakt. Nöggerath was eveneens een oudgediende in de bioscoopbranche. Hij bezat twee bioscopen in Amsterdam, één in Den Haag en verder ook nog het filmverhuurbedrijf Fan. Barnstijn begon in I9I4 als bioscoopexploitant, eerst in Den Haag en later ook in andere steden. Tijdens de oorlogsjaren was hij bovendien in de filmimport- en verhuur actief geworden. Met name hierdoor groeide hij in I9I8 uit tot een van de belangrijkste spelers in het Nederlandse filmbedrijf.

I8 Filmverhuurders mochten alleen donateur worden van de Exploitantenbond.

I9 Dibbets, 'Bioscoopbedrijf tussen twee wereldoorlogen', p. 239.

20 De Bioscoop-Courant, 7 februari igig.

2I Dibbets, 'Bioscoopbedrijf tussen twee wereldoorlogen', p. 252. Eva van der Mars, 'De Rotterdamse filmdistributieen bioscoopbranche, I9I2-I923. Een historisch onderzoek op basis van de vakpers'. Doctoraalscriptie Universiteit Utrecht, 2005; Bijlage I: Spanningen in de verhuurbranche: H.A.P.-Film en De Bioscoop-Courant, p. 82-87.

22 Ze kregen ruzie over de vorm van de arbeidscontracten die in het amusementsbedrijf gehanteerd zouden moeten worden. De Bioscoop-Courant, Io oktober I9I9.

23 Tot de naamsverandering werd besloten in september I9I9. Dibbets, 'Bioscoopbedrijf tussen twee wereldoorlogen', p. 252.

24 Kunst en Amusement, 24 december 1920.

25 Volgens Kunst en Amusement, 9 juli 1920.

26 De Film, 6 februari I920, stelde het ledenaantal van de Directeurenbond begin I920 op i6o. Kunst en Amusement meldde op 7 mei I920 dat het ledental tussen april I9I9 en mei I920 gestegen was van I30 tot I7I, maar daarvan waren slechts I32 leden bioscoopexploitanten. De rest was donateur en naar alle waarschijnlijkheid binnen het filmbedrijf actief als verhuurder of in een andere rol.

27 Kunst en Amusement, 23 januari i920.

28 Een verwijzing naar het 'niet voldoen van huurpenningen' aan verhuurders door exploitanten als veelvoorkomende misstand in het filmbedrijf staat o.a. in Kunst en Amusement, 7 januari I92I.

29 Naast de Amerikaanse Hollywood studio's paste ook de Duitse UFA vanaf de oprichting in I9I7 verticale integratie toe. Voor de Eerste Wereldoorlog deed het Franse Pathé - toen een zeer dominante speler op de internationale 
filmmarkt - al hetzelfde.

30 Kunst en Amusement, 2I januari I92I.

3I Nieuwe Tilburgsche Courant, 20 januari I92I.

32 Gemeentearchief Rotterdam (GAR), archief R.S. Stokvis \& Zonen, toegangsnr. 355, bestanddeel 568, 'stuk betreffende de opzet van de Bioscoop-Trust', gedateerd I december I920. Het verhuurkantoor waar Loet Barnstijn bekend mee was geworden, de HAP Film Company, droeg hij over aan zijn broer Eduard.

33 Kunst en Amusement, ir februari ig2I.

34 Gemeentearchief Rotterdam (GAR), archief R.S. Stokvis \& Zonen, toegangsnr. 355, bestanddeel 568, 'stuk betreffende de opzet van de Bioscoop-Trust', gedateerd I december I920.

35 Kunst en Amusement, 7 januari I92I.

36 In januari I92I werd vooruitlopend op de vorming van een nieuwe koepelorganisatie het besluit genomen dat verhuurders, behalve donateur, ook lid van de Exploitantenbond konden zijn. In dezelfde maand stelde men een Commissie voor Geschillen in, om de vele conflicten tussen leveranciers en afnemers, bijvoorbeeld over het niet of te laat betalen van filmhuren et cetera, intern te beslechten. Zie ook Dibbets, 'Bioscoopbedrijf tussen twee wereldoorlogen', p. 254 .

37 Het bestuur van de Bond was op dat moment als volgt samengesteld: W. Mullens (voorzitter), D. Hamburger Jr (vice-voorzitter), R. Minden (secretaris), E. de Hoop Azn. (penningmeester), J. Kroonenberg (lid), André de Jong (lid), L. Schetzer (lid), N.H. Wolf (administrateur).

38 Thunnis van Oort, Film en het moderne leven in Limburg, Verloren, Hilversum 2007, p. 69-93. De man die de bond opriep tot dit ingrijpen was Eduard Cohen Barnstijn, een broer van Loet.

39 Kunst en Amusement, 4 maart I92I.

40 Kunst en Amusement, II maart I92I; Nieuwe Rotterdamsche Courant, 5 maart I92I; Het Vaderland, 23 en 27 maart I92I.

4I Kunst en Amusement, 22 juli I92I.

42 Het betreft hier de algemene condities opgesteld door de NBB voor de huur en verhuur van films en rechten en plichten van huurder en verhuurder, opgenomen in de statuten van de Bond, aangenomen in de Algemene Vergadering in maart I923. Leden van de Bond moesten in hun zakelijke overeenkomsten, zowel met leden als met niet-leden, de bepaling ‘onder Bondsvoorwaarden' opnemen. Later zou de Bond in een modelcontract gaan voorzien, waarvan de leden niet mochten afwijken.

43 In I924 werd het definitieve standaardcontract voor alle ondernemers in het filmbedrijf die lid waren van de Bond verbindend verklaard. Dibbets, Geschiedenis van de Nederlandse film en bioscoop, p. 254.

44 Wolf was daarnaast hoofdredacteur van De Kunst, een blad voor het grote publiek, waarin hij onder andere geregeld schreef over film.

45 Kunst en Amusement, I7 september i920. Voor een terugblik van Wolf op deze plannenmakerij, zie: Kunst en Amusement, I juni i923.

46 Bijvoorbeeld in Kunst en Amusement, I5 december 1922.

47 Kunst en Amusement, II mei I923, 28 december I923.

48 Kunst en Amusement, I4 december I923.

49 Nieuw Weekblad voor de Cinematografie, 3 april I925.

50 Nieuw Weekblad voor de Cinematografie, 3, I0, I7 en 24 april I925.

5I Nieuw Weekblad voor de Cinematografie, I mei I925.

52 Nieuw Weekblad voor de Cinematografie, I mei I925.

53 Nieuw Weekblad voor de Cinematografie, I mei I925.

54 Rotterdamsch Nieuwsblad, 4 juni I924.

$55 \mathrm{Al}$ medio I924 verschenen berichten in de pers dat de NBT verlies maakte en problemen had met het aflossen van zijn hypotheekschulden. Zie o.a. de Telegraaf, 3i mei en 2 juni i924.

56 Het Vaderland, 21 april I926; NRC, 22 april I926.

57 Dibbets, 'Bioscoopbedrijf tussen twee wereldoorlogen', p. 256. 